\title{
optix is involved in eyespot development via a possible positional information mechanism
}

Tirtha Das Banerjee ${ }^{1, *}$, Seah Kwi Shan ${ }^{1}$, and Antónia Monteiro ${ }^{1,2, *}$

\author{
Affiliations \\ 1 Department of Biological Sciences, National University of Singapore, Singapore - 117557. \\ 2 Yale-NUS College, Singapore - 138527. \\ * Authors for correspondence \\ Email: tirtha_banerjee@u.nus.edu, antonia.monterio@nus.edu.sg
}

\begin{abstract}
optix, a gene essential and sufficient for eye development in Drosophila melanogaster, also plays important roles in the development of both the structure and pigmentation of butterfly wing scales. In particular, optix regulates wing scale lower lamina thickness and ommochrome pigment synthesis. Here we explore the role of optix in wing pattern development of Bicyclus anynana butterflies by examining its expression using immunostainings and testing its function via CRISPR-Cas9. We found Optix to be expressed in multiple domains, most prominently in the orange ring of the eyespots and in other scattered orange scales, and to regulate the pigmentation and the development of the upper lamina of the orange scales. We further explored the interaction of Optix with Spalt, a protein involved in the development of black scales in the eyespots, and expressed adjacent to the Optix domain. CRISPR knockouts of optix or spalt, followed by immunostainings, showed that Spalt represses optix expression in cells of the central black region of the eyespot. This regulatory interaction mimics that found in the anterior compartment of the wing disc where both genes respond to Decapentaplegic (Dpp) signaling and play a role in venation patterning. Using in situ hybridizations we show that $d p p$ is expressed in the center of the eyespots and propose that this same circuit might have been recruited for eyespot development where Decapentaplegic acts as a central morphogen, activating optix and spalt at different concentration thresholds, and where spalt cross-regulates optix resulting in the formation of a sharp boundary between the two eyespot color rings.
\end{abstract}

\section{Keywords}

Optix, decapentaplegic, Spalt, positional information, eyespots, Bicyclus anynana

\section{Introduction}

optix, a member of the sine oculis homolog (six/so) gene family is involved in eye morphogenesis and wing patterning in the model vinegar fly Drosophila melanogaster (A1 Khatib et al., 2017; Martín et al., 2017; Seimiya and Gehring, 2000). Ectopic expression of optix is sufficient to induce the development of eyes via a mechanism independent of eyeless, a gene previously implicated in eye morphogenesis (Quiring et al., 1994; Seimiya and Gehring, 2000), whereas loss of optix impairs eye development (Li et al., 2013) and the development of the anterior part of the fly's wing (Al Khatib et al., 2017; Martín et al., 2017).

In butterflies, optix has been primarily investigated with respect to color pattern development and wing scale morphology. optix is considered one of the hotspot genes along with WntA, aristaless, and cortex, where allelic variants result in a wide array of wing pattern variation in 
Heliconius butterflies (Jiggins et al., 2017; Reed et al., 2011). In Heliconius, Agraulis, Junonia, and Vanessa butterflies, optix has been shown to be involved in the development of ommochrome pigments, as optix crispants result in the loss of red and orange pigments along with the downregulation of ommochrome associated genes such as cinnabar and kynurenine formamidase (Zhang et al., 2017). In Junonia coenia, mutations in optix result in the development of blue iridescent scales (Zhang et al., 2017) as a result of decreased ommochrome production, increased melanin production, and increased lower lamina thickness of the scales (Thayer et al., 2020). Optix is expressed in a few other domains and scale types, primarily along the veins of both male Dryas julia (Martin et al., 2014), and male Agraulis vanillae (Martin et al., 2014; Rauser and Rutowski, 2003) but its function has not yet been investigated in these species.

Eyespots in Bicyclus anynana butterflies contain a circular ring which is orange in color and might contain ommochrome pigments, but, the expression and function of optix in eyespot development has not yet been explored. Here we studied optix both at the expression and functional levels focusing on the eyespots. We also explored the possible interaction of optix with other genes involved in eyespot development such as spalt and decapentaplegic ( $d p p)$, to further build our understanding of the gene regulatory network underlying eyespot development, and integrate optix into that network.

\section{Results}

\section{Expression and function of Optix in eyespots}

To examine whether Optix is expressed in the pupal wings of Bicyclus we used immunostains. Optix is expressed prominently in the orange ring of the eyespots from 24-72 hrs (Figure 1CF) of pupal development. To test the function of optix we used injections of Crispr/Cas9 into early embryos. Individuals that emerge from these injections are usually mosaics where some cells have been disrupted for optix function whereas others are wildtype. Some of these individuals showed transformation of their orange colored scales to a brown color (Figure 1GJ). To confirm that these phenotypes were due to the loss of Optix expression, we performed Optix immunostains in some of the injected animals at the pupal stage of development. This revealed that Optix expression was missing from cells of the orange ring of the eyespots (Figure 1K and L). Finally, we confirmed that knocking out optix led to deletion of nucleotides mostly near the targeted sites (Figure $1 \mathbf{M}$ and $\mathbf{N}$ ). 
bioRxiv preprint doi: https://doi.org/10.1101/2021.05.22.445259; this version posted May 23, 2021. The copyright holder for this preprint (which was not certified by peer review) is the author/funder, who has granted bioRxiv a license to display the preprint in perpetuity. It is made available under aCC-BY-ND 4.0 International license.
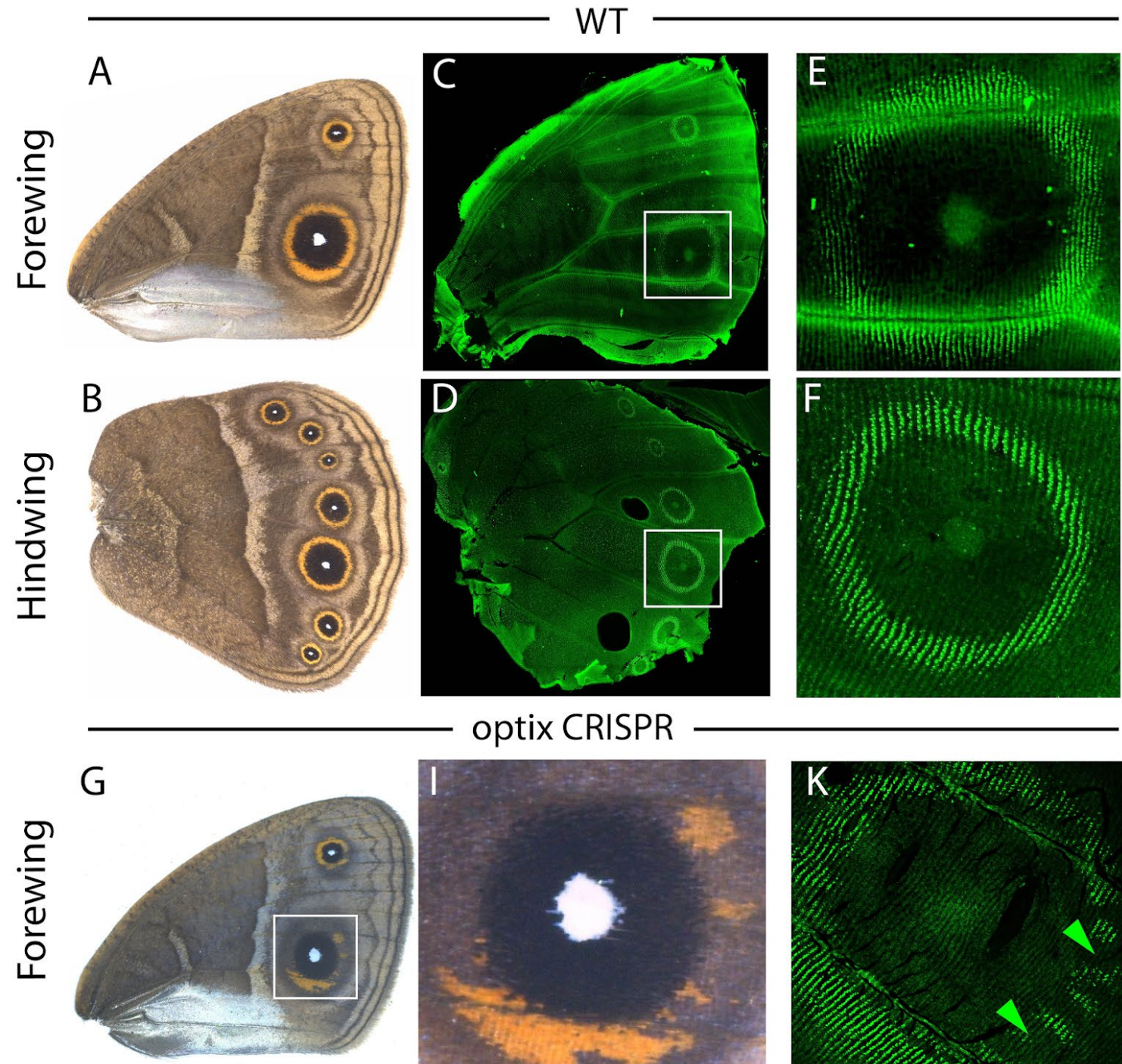

\section{optix CRISPR}
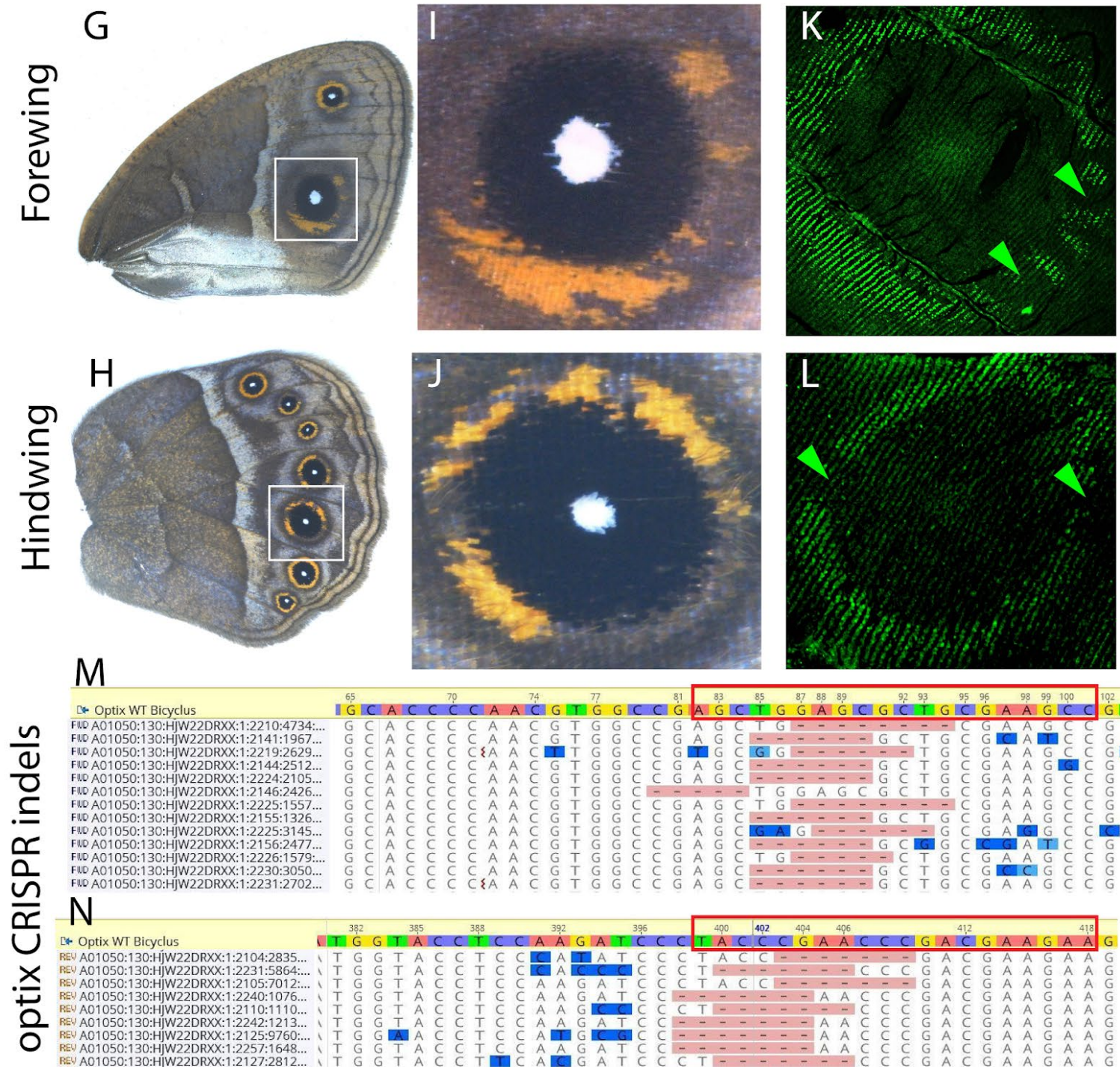
bioRxiv preprint doi: https://doi. org/10.1101/2021.05.22 445259; this version posted May 23,2021 . The copyright holder for this preprint (which was not certified by peer review) is the author/funder, who has granted bioRxiv a license to display the preprint in perpetuity. It is made available under aCC-BY-ND 4.0 International license.

Figure 1. Expression and function of Optix in the wings of Bicyclus anynana two days after pupation. (A) WT forewing, (B) WT hindwing. (C) The expression of Optix in the forewing and (D) in the hindwing. (E and F) Expression of Optix in the eyespot orange ring of $\mathrm{Cu} 1$ eyespots. (G-J) CRISPR-Cas9 knockout of optix in the forewing and hindwing produces defects in the development of the eyespot's orange ring. (K and L) optix CRISPR results in the loss of Optix in cells of the future orange ring area of the eyespots. (M and $\mathbf{N})$ CRISPR deletions at the optix target sites.

\section{Transformation of scale structure in the eyespots due to optix knock-out}

Because previous studies have shown that optix alters the morphology of scales in other species (Zhang et al., 2017; Thayer et al., 2020), we decided to examine the morphology of the differently colored scales in Bicyclus eyespots using a scanning electron microscope (SEM). Knocking-out optix resulted in the loss of a thin upper lamina that connects the crossribs in part of the upper surface of the orange scales (Figure 2B and C). This modification makes these scales resemble the morphology of WT brown scales (Figure 2D). The structure of black and white scales, however, was not affected (Figure S2).

\section{Changes in pigmentation due to optix knock-out}

Optix has also been shown to play role in controlling melanin and ommochrome pigmentation (Zhang et al., 2017). To quantify the pigmentation changes to the orange scales due to optix knockout, we used a spectrophotometer and measured scale absorbance of WT, altered orange scales, and brown scales in eyespots. Knocking out optix resulted in a change of the absorbance spectra of the wing from orange to brown at the orange scale region resembling the color of WT brown scales (Figure 2E). This indicates that brown, likely melanin pigments, replaced the orange pigments in these scales. 

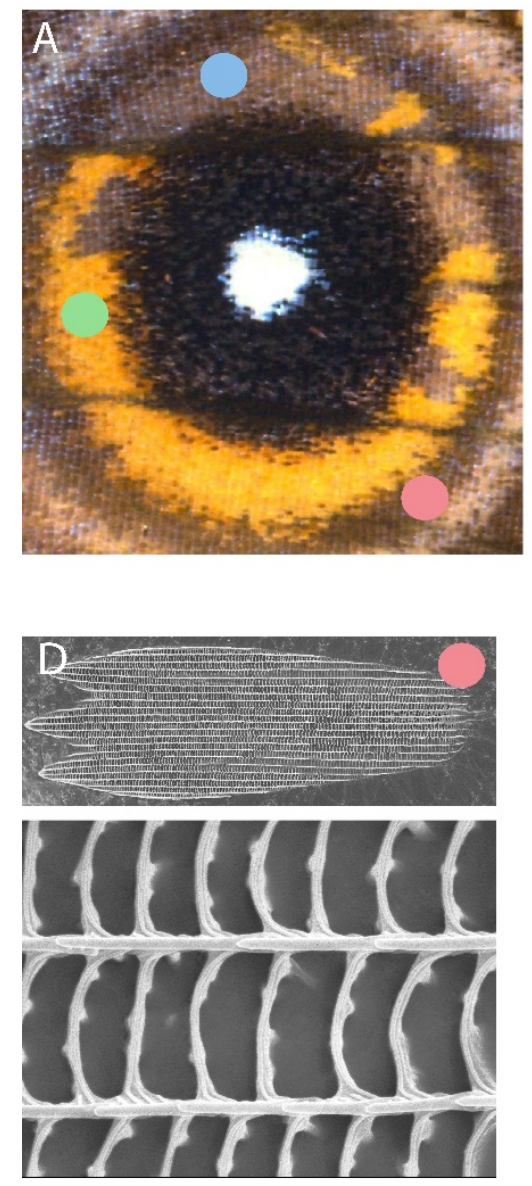

WT brown

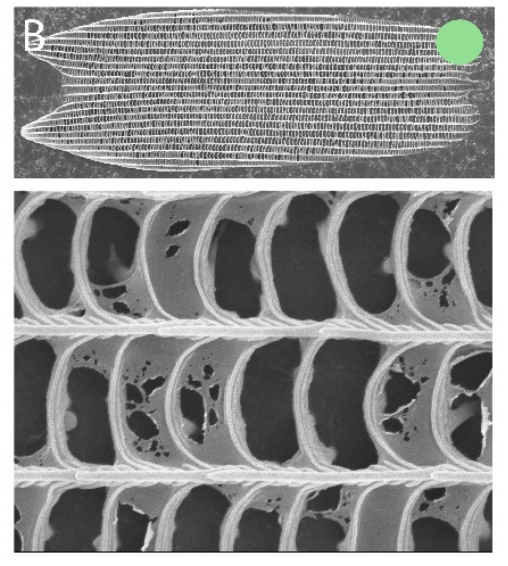

WT orange

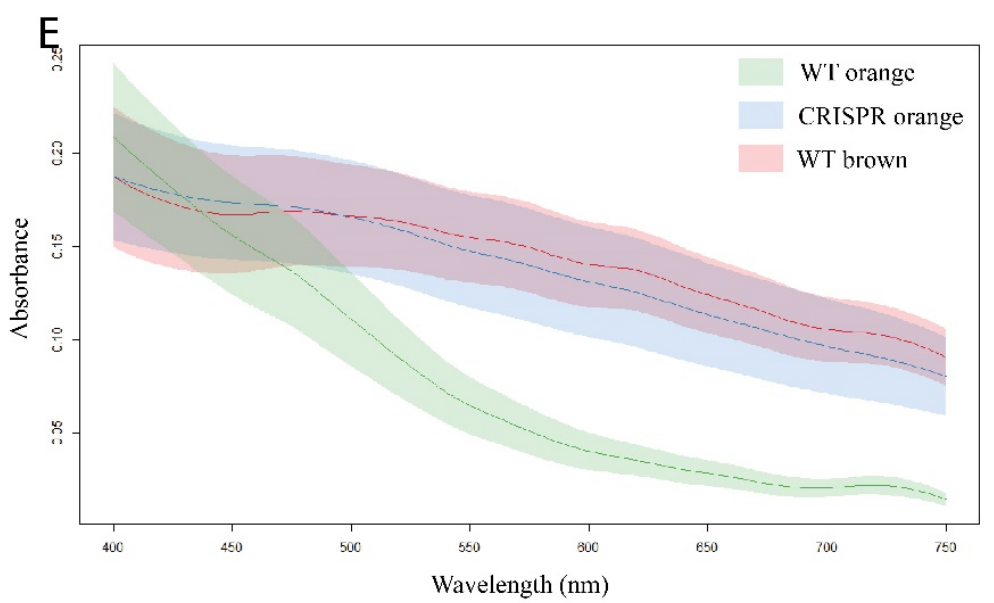

Figure 2. Optix promotes the development of a thin upper lamina and of orange pigments in the orange scales. (A) optix knockout results in the conversion of orange scales into brown scales. SEM images of (B) an orange scale from the orange ring, $(\mathbf{C})$ an optix CRISPR modified scale from the same ring, and (D) a brown scale from an outer ring. Knocking out optix results in the reduction of a thin upper lamina found in orange scales, and thicker crossribs, making these scales resemble the morphology of brown scales. (E) Absorbance spectra of WT and optix CRISPR scale patches. Knocking-out optix results in the conversion of the absorbance spectra of orange scales to that of brown scales, indicating a change in pigments. The color shading around the black curves indicates the standard deviation of the spectral measurement for each scale type from four individuals. Colored dots represent the areas used for scale sampling and spectrophotometric analysis.

\section{Expression of decapentaplegic (dpp) and the interaction of Optix and Spalt in the eyespots}

Optix expression in a ring around the eyespot suggests that this gene could be responding to a centrally produced morphogen. In Drosophila larval wing discs, the morphogen Decapentaplegic (Dpp), expressed in a stripe along the anterior-posterior axis (Zecca et al., 1996) is known to activate optix in the upper anterior wing compartment (Martín et al., 2017). Dpp also activates spalt in a stripe of cells, closer to the Dpp source, that straddles both the anterior and posterior compartments (Sturtevant et al., 1997). Spalt, in turn, represses optix from its own domain producing a sharp boundary in the expression of the two genes that determines the position of the L2 longitudinal vein in flies (Martín et al., 2017). In order to 
explore whether the same morphogen, Dpp, might be involved in activating optix in a ring around the eyespot in Bicyclus butterflies we performed in situ hybridizations with a probe for $d p p$. The in situ data indicate that $d p p$ is expressed in the eyespot centers in $18 \mathrm{hrs}$ old pupal wings (Figure 3A and B), which overlaps the window of development when Optix becomes expressed in the orange ring.

To further pursue similarities between the fly wing venation patterning mechanism and eyespot patterning we first examined the expression of Optix and Spalt with double immunostainings and then examined their regulatory interaction. In Bicyclus Spalt shows expression in the eyespot centers and in the tissues where the future black scales are going to form (Figure 3C and D). The expression of Optix in the orange ring (Figure 3E and F) starts at a sharp boundary where the expression of Spalt ends in the future black scale cells (Figure 3G and H; green arrow). In some individuals, expression of Optix is also observed in the center of the eyespots at 16-20 hrs pupal wing development (Figure 3E and F).

To test the regulatory interactions between spalt and optix in Bicyclus eyespots, we performed knockouts of each gene in turn, followed by immunostainings targeting the protein products of both genes. Optix crispants that showed loss of orange pigments in the orange scales (Figure 4B), and loss of Optix expression in cells of the orange ring (Figure 4E) did not show changes in the area of black scales (Figure 4B) or in the expression of Spalt in those cells (Figure 4H and K). These data indicate that Optix is involved in giving the orange rings their color, but this gene is not involved in regulating the outer perimeter of the black scales or Spalt expression in the eyespots. Spalt crispants showed the development of orange scales in the black scale region of the eyespots (Figure 4C), loss of Spalt (Figure 4I), and ectopic expression of Optix in the black scale region (Figure 4F and L; Figure S6E). These data indicate that Spalt represses optix expression in the central black disc region of the eyespot, where loss of spalt leads to activation of optix in this region and to a change in scale color from black to orange. 


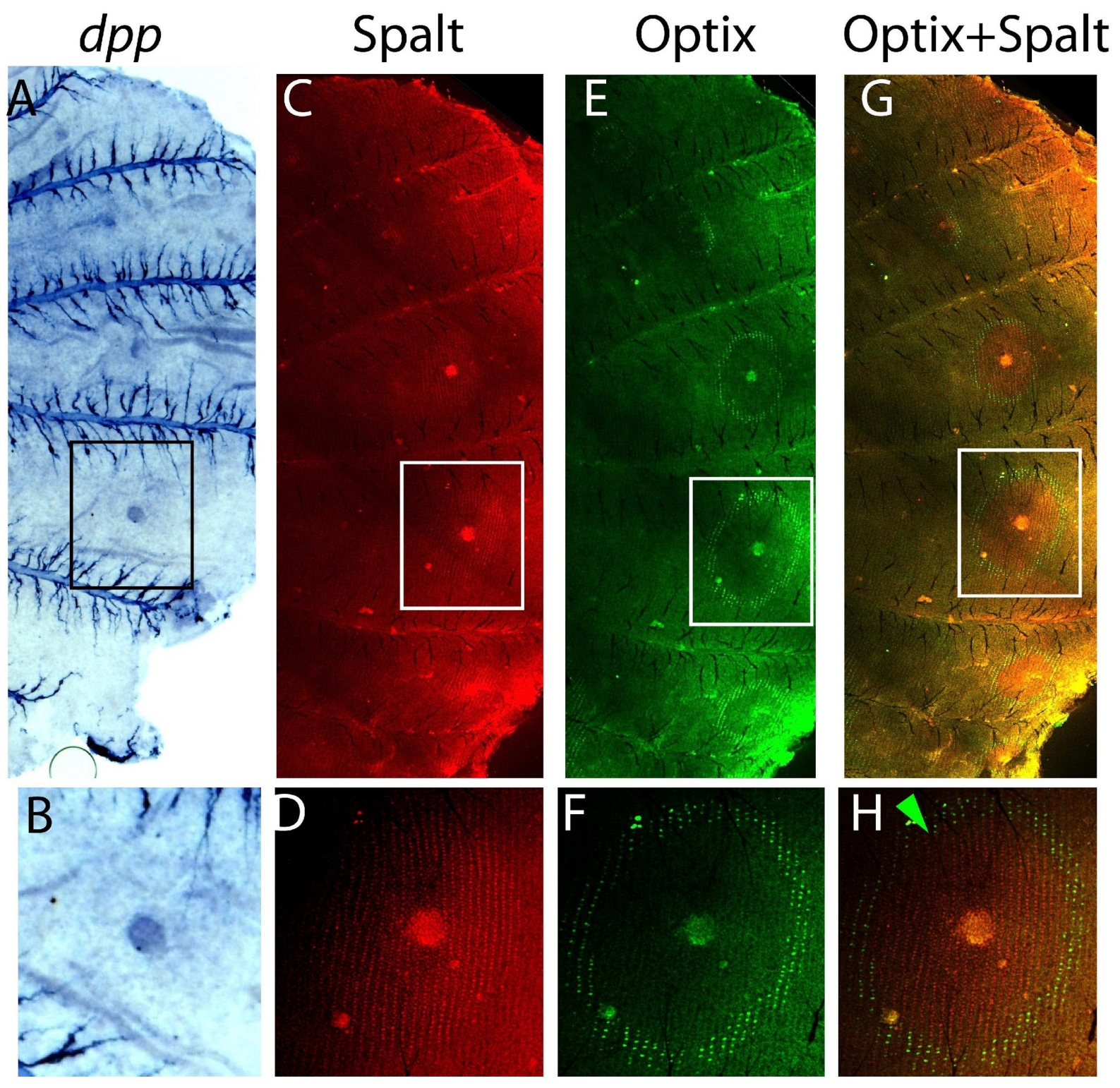

Figure 3. Expression of decapentaplegic (dpp), Spalt, and Optix in 16-20 hrs pupal wings. (A and B) Expression of $d p p$ in the eyespot centers at $18 \mathrm{hrs}$ after pupation. (C and D) Expression of Spalt in the eyespot centers and in the future black scales at 16-20 hrs after pupation. (E and F) Expression of Optix in the eyespot centers and in the future ring of orange scales in the same wing. (G and $\mathbf{H}$ ) Merged channels of Optix and Spalt. The boundary where Spalt expression stops and Optix expression starts is marked by a green arrow. 

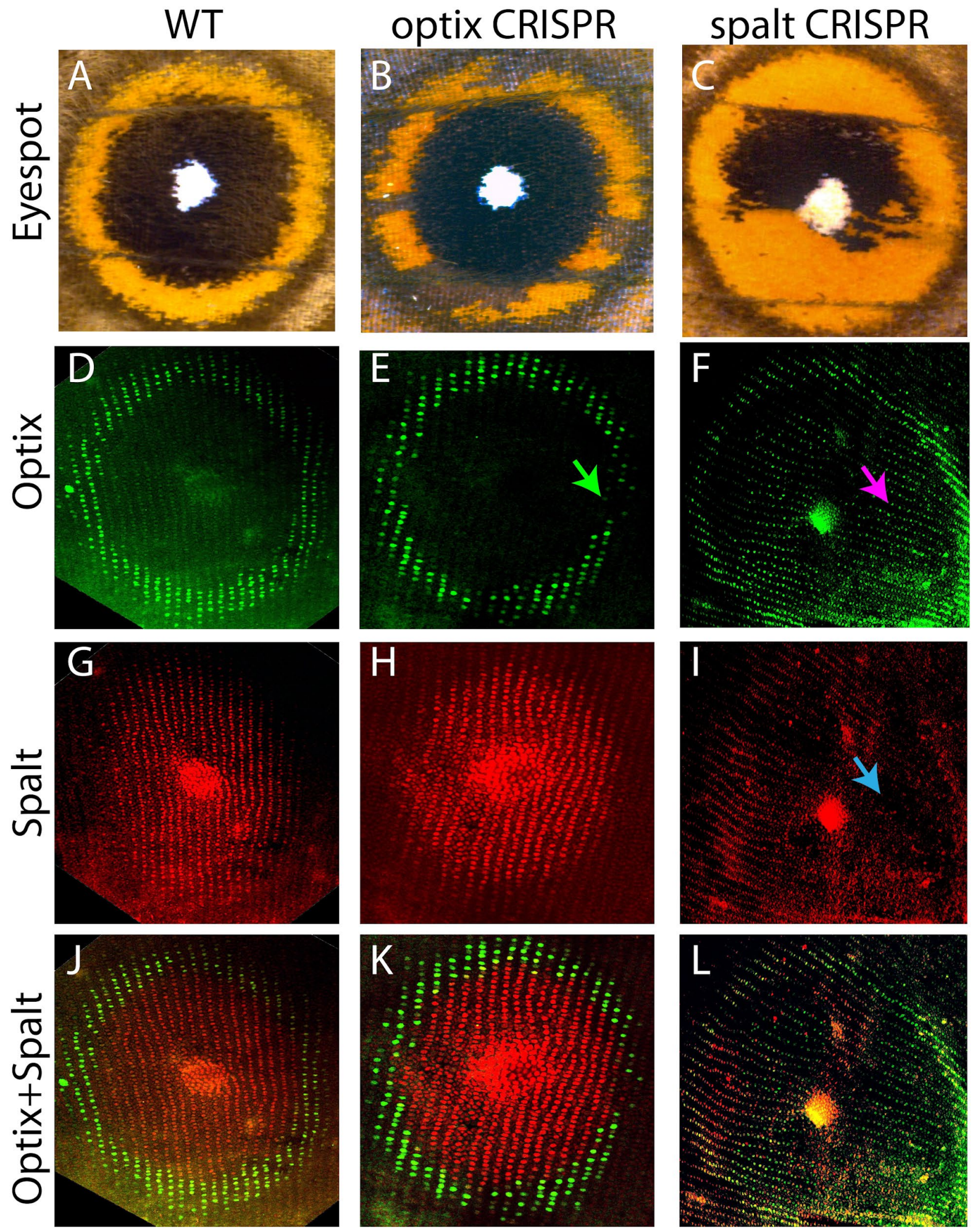

Figure 4. Spalt prevents optix from being expressed in the black disc region of the eyespot (16-20 hrs pupal development). (A) WT eyespot, (B) optix CRISPR eyespot, and (C) spalt CRISPR eyespot. (D-F) Eyespots stained with an antibody against Optix in WT optix CRISPR and spalt CRISPR individuals. (G-I) Eyespots stained with an antibody against Spalt in WT, optix CRISPR and spalt CRISPR individuals. (J-L) Merged channels of Spalt and Optix. Green arrow marks the region of missing Optix protein in the optix CRISPR individual. The 
bioRxiv preprint doi: https://doi org/10.1101/2021.05.22.445259; this version posted May 23, 2021. The copyright holder for this preprint

expression of Spalt is not affected due to the absence of Optix. Pink arrow marks the ectopic expression of Optix, where Spalt expression is missing (blue arrow).

Both Optix and Spalt are co-expressed in the center of the eyespots in some individuals where they show a different interaction (Figure 3H; Figure 4L). Disruptions of optix, however, don't produce any defects in the scale ultrastructure of the white scales (Figure 4B; Figure S1-S2).

\section{Discussion}

\section{Optix controls both pigmentation and scale ultrastructure development}

In this work we discovered conserved as well as novel functions for optix that were not previously described. The conserved function involves Optix regulating the orange color of the eyespots in Bicyclus butterflies. This function is similar to that previously described in Heliconius erato, Agraulis vanilla, Vanessa cardui and Junonia coenia butterflies where optix knockouts resulted in the loss of red and orange pigments and in the down-regulation of key ommochrome pigmentation genes (Reed et al., 2011; Zhang et al., 2017). Our results suggest that the pigment in the orange ring of the eyespots is an ommochrome as well. In our experiments, the orange pigment was substituted by a brown pigment (Figure 2A and E), likely a melanin. This also appears to be a conserved function for Optix, that acts as a switch to toggle the production of ommochromes and melanins in Heliconius and Junonia butterflies (Zhang et al., 2017). The novel results pertain to Optix being expressed in a novel wing pattern, not previously examined, eyespots, and in altering the morphology of orange scale cells in a novel way. We will first discuss the effects of Optix on scale morphology, and then the cooption of optix into eyespot development.

The effect of optix on scale morphology in Bicyclus appears to be different from those previously described in other butterfly species. In Bicyclus, Optix seems to be required to form a chitin lamina that partially covers the windows or spaces between the crossribs (the upper lamina) of the orange scales. Previous work in Junonia coenia showed that optix was involved in determining the thickness of the lower lamina of background orange/brown scales, where disruptions of optix resulted in increased thickness of the lower lamina along with pigmentary changes (Thayer et al., 2020). Optix, thus, appears to function in thinning the lower lamina in Junonia, and in building the upper lamina in Bicyclus scales. Because we did not measure the lower lamina thickness in Bicyclus in Optix crispants, it remains possible that the absence of Optix might have led to a shuttling of chitin that is normally deposited in the upper lamina to the lower part of the scale cell, increasing the thickness of the lower lamina, as seen in Junonia Optix crispants.

Optix might regulate lamina thickness in a scale cell in different ways. Thayer et al., (2020) proposed that this transcription factor could regulate the transcription of enzymes such as chitin synthase, involved in the formation of chitin (Merzendorfer and Zimoch, 2003), in addition to regulating the ommochrome synthesis enzymes. This suggests a pleiotropic function for Optix proteins. Another possibility, proposed by Matsuoka and Monteiro (2018), is that the presence of particular pigments inside a scale cell lead chitin to polymerize in particular ways. This latter mechanism is supported by loss of function experiments with more downstream pigmentation enzymes of the melanin pathway, or cell-cycle regulators, that should not have any gene regulatory functions. For instance, the gene yellow, required for the synthesis of the black pigment dopa-melanin, is also required for the polymerization of chitin around crossribs. When 
yellow is disrupted, scales loose black pigment, crossribs become thin, and an upper lamina of chitin forms in Bicyclus black scales. The gene $D D C$, which is required for the synthesis of the brown pigment dopamine-melanin, is also required for the polymerization of chitin around pillar trabeculae. When $D D C$ is disrupted, brown pigment is lost, and chitin polymerizes in vertical sheets, instead of in round pillars (Matsuoka and Monteiro). cortex, a cell cycle regulator, plays a role in melanin synthesis in Biston betularia and Heliconius butterflies (Nadeau et al., 2016; van't Hof et al., 2016). Loss of cortex affects black pigmentation and increase the extent of the upper lamina of the black scales (Livraghi et al., 2020). In sum, these experiments suggest that ommochromes and melanins such as dopa-melanin, dopaminemelanin, xanthommatin, and dihydroxanthommatin might be directly involved in polymerizing chitin in particular patterns inside a scale cell and in regulating scale morphology. The toggle function of Optix, of replacing melanins by ommochromes, might be responsible for the observed wildtype morphology in orange scales. By simply removing melanins from these scales Optix prevents chitin from polymerizing around the crossribs or trabeculae, and leads to the production of a thin upper lamina.

\section{Optix, together with a larger pre-existent gene network were co-opted to a novel domain in eyespots}

A new discovery reported here is that Optix was co-opted into eyespot development and plays an important role in color ring differentiation. The mechanism of ring differentiation in an eyespot has been hypothesized to involve a centrally produced morphogen that activates genes at a distance from the source in a concentration-dependent manner (Beldade and Monteiro, 2021; Monteiro et al., 2006; Nijhout, 1978). optix is, thus, a gene that could be directly or indirectly responding to low levels of the morphogen along a ring of cells around the source. A known positional information mechanism, involving Optix being activated by low levels of the morphogen Dpp operates in fly wings during larval development, and plays an important role in vein patterning (Martín et al., 2017). Recently, we showed that this vein-positioning mechanism appears to be conserved in early larval wing discs of Bicyclus, with Optix being expressed at some distance away from two linear sources of Dpp (Banerjee and Monteiro 2020). This inspired us to investigate the expression of Dpp in early pupal wings of Bicyclus, to test whether such a genetic circuit might have been co-opted, wholesale, to eyespot development. Previous work had already suggested that a BMP ligand was expressed in eyespot centers in early pupae because an active signal transducer for this pathway, phosphorylated Mothers Against Dpp (pMad), was visualized in the eyespot centers (Monteiro et al. 2006), but the identity of this ligand was still unknown. Here we show that Dpp is indeed expressed in the eyespot centers (Figure 3A and B) suggesting that the genetic circuit that positions veins in early wing discs of flies and butterflies might have been reused to position color rings in eyespots, around a novel source of Dpp.

We also show that eyespots and this early vein positional information mechanism share additional similarities, such as in the expression of Spalt. In the larval wing discs of Drosophila Dpp activates spalt at a higher concentration threshold, in a stripe of cell abutting the Dpp source, and optix at a lower concentration threshold in a stripe further away in the anterior wing disc(Figure 5A; (Al Khatib et al., 2017; Martín et al., 2017)). Spalt is also a repressor of optix, and as a result optix expression is only observed where Spalt expression ends, in the upper anterior compartment of the fly wing disc (Figure 5A, (Martín et al., 2017)). The complementary expression of Spalt and Optix creates a perfect boundary between these two genes where a vein specific gene knirps (a gene repressed by both Spalt and Optix) determines the fate of provein cells (Martín et al., 2017). Thus, the complex interaction of these multiple genes results in the development of a single vein via a positional information mechanism. A 
recent study has proposed a similar mechanism to be in play in butterflies as well, where the Spalt expression domain is observed abutting both the $d p p$ and the Optix expression domains (Banerjee and Monteiro, 2020b; Figure 5B).

Here we show that the regulatory interaction between Spalt and Optix observed in early larval wing discs of Drosophila, where Spalt represses optix and keeps it out of its expression domain, is present in the eyespots of Bicyclus. In particular, loss of Spalt results in ectopic expression of Optix in the black scale area, indicating that Spalt is repressing the activation of optix in the black scale area (Figure 4; Figure S4). In the Drosophila wing disc a similar down-regulation of spalt with RNAi led to the expansion of the Optix domain in the anterior compartment (Martín et al., 2017). In Bicyclus, disruptions to optix led to the loss of Optix protein in the orange ring precursor cells, but did not affect the expression domain of Spalt (Figure 4). These results are also consistent with Drosophila wing vein patterning, where downregulation of optix with RNAi did not affect the expression domain of Spalt (Martín et al., 2017). Overexpression of optix, however, reduced the Spalt domain in the wing disc (Martín et al., 2017).

In summary, we propose that the genetic circuit involving Dpp, Spalt and Optix, complete with its cross-regulatory interactions has been co-opted whole-sale from a vein patterning function, in the early larval wings of butterflies, to eyespot development in the later pupal stages.
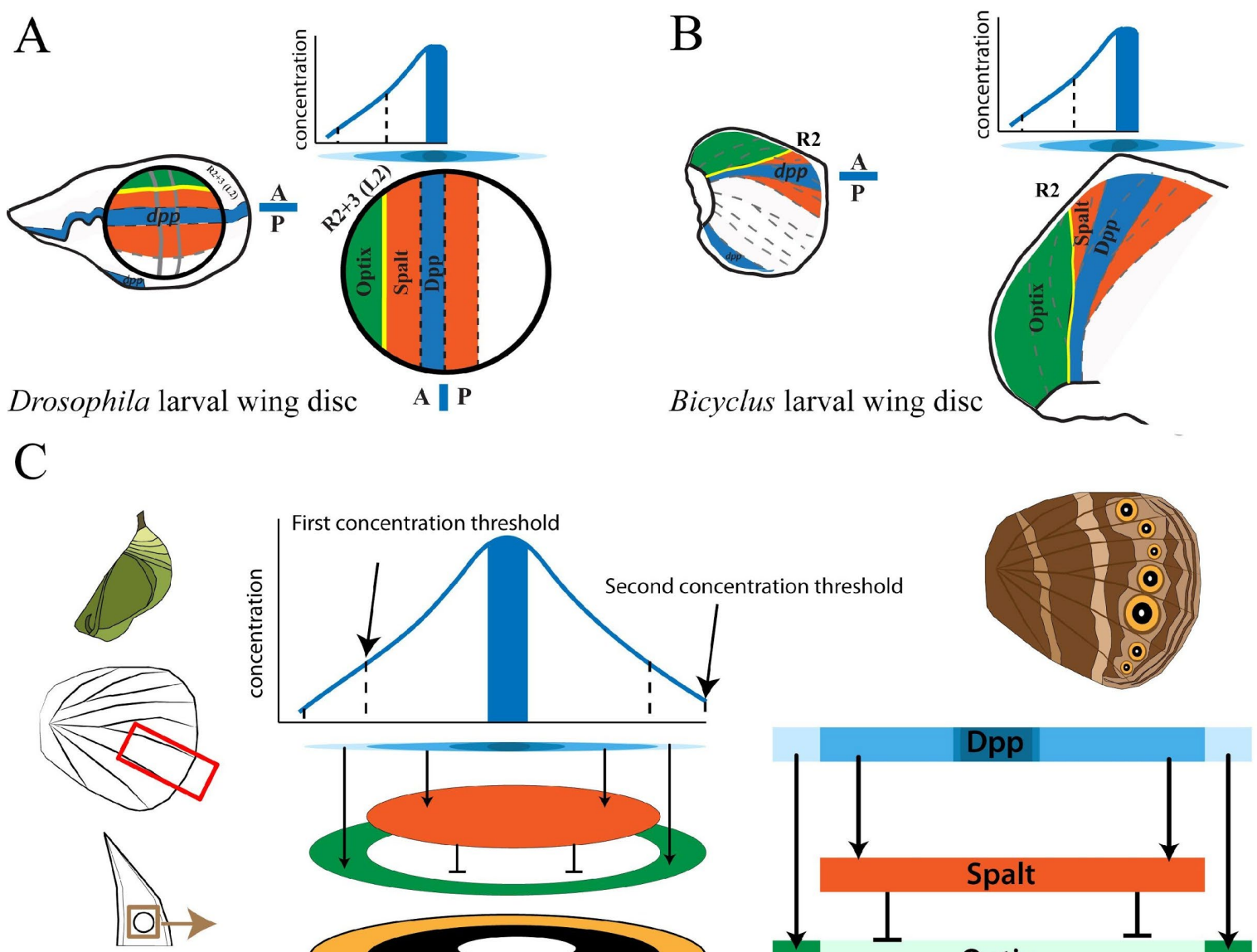

Bicyclus eyespot
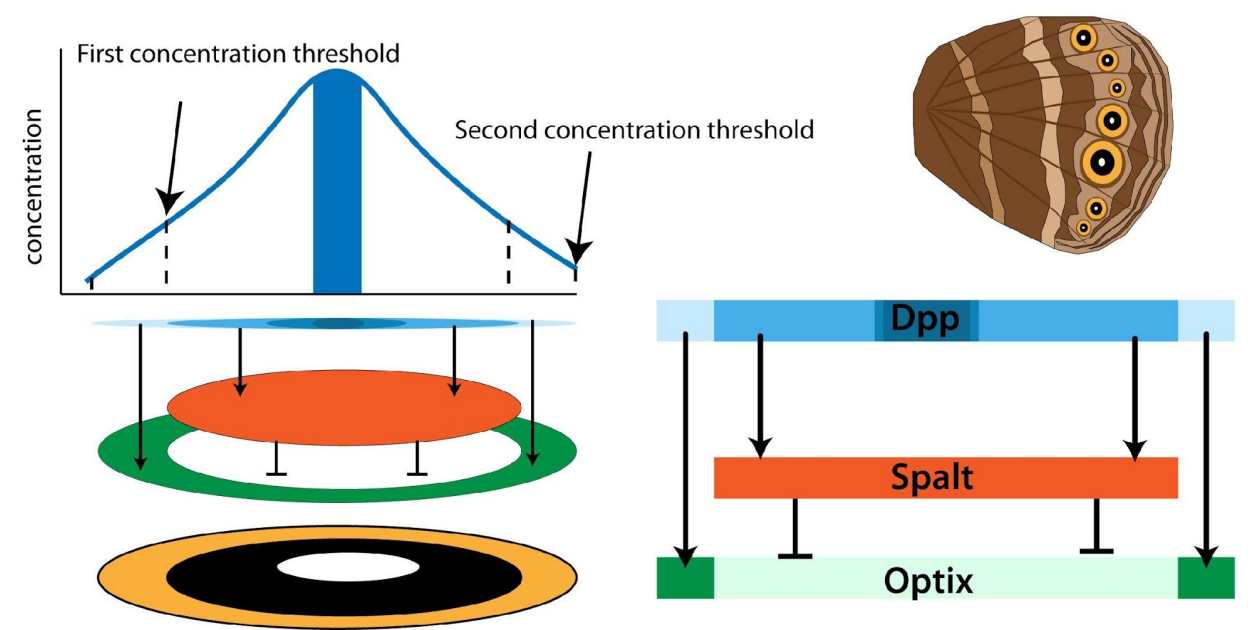

Figure 5. A positional information model for the eyespot pattern formation via a mechanism similar to the anterior-posterior wing network. (A) Positioning of Drosophila R2+3 (L2) vein via Dpp (blue). Dpp diffuses from the AP boundary and activates Spalt (orange) and Optix (green) at different concentration threshold. Spalt represses the activation Optix at the cell's posterior to the vein L2. The cells in between Spalt and Optix expresses 
knirps (co-repressed by Spalt and Optix) which leads to the development of L2 provein cells (Martín et al., 2017). (B) Proposed positioning of Bicyclus R2 vein via Dpp (blue) via the same mechanism as discussed above for Drosophila (Banerjee and Monteiro, 2020a). (C) A mechanism identical to that involved in patterning the AP axis of the wing might be involved in eyespot ring differentiation. In the eyespots the $d p p$ gene (blue) is expressed in the central cells. The Dpp protein might act as a morphogen diffusing to the surrounding tissues and activating Spalt and Optix at different concentration thresholds. Spalt represses the activation of optix in the inner black scale area, and as a result, Optix is expressed only in the outer orange ring region.

The expression of Optix in the white scale cells in some individuals in between 16-20 hrs of pupal wing development (Figure 3F and Figure 4F) might represent an independent cooption, separate from the circuit described above. It is also unclear what the function of optix is here, as we observed no altered phenotypes in these scales. One possibility is that optix might play a role in the development of orange scales in dry season forms of this butterfly, which display darker centers for purposes of better crypsis (Monteiro et al. 2015; Bergen and Beldade, 2019). Elucidating the role of Optix in these scales, in connection with seasonal plasticity in this butterfly, would be of interest for a future study.

Also, of interest for a future study is to explore how other genes that are also expressed in the black and orange scales can be integrated, if at all, into the current network. For example, Engrailed is co-expressed with Optix in the orange ring scales (Figure S5) and Distal-less is co-expressed with Spalt in the black scales (Brunetti et al., 2001). Similar experiments to the ones described here, where one gene is knocked-out followed by examination of expression of the other genes is a possible avenue to this.

\section{Methods}

\section{Rearing Bicyclus anynana}

Bicyclus butterflies were raised in the lab at $27^{\circ} \mathrm{C}, 60 \%$ humidity and $12-12 \mathrm{hrs}$ day-night cycle. Larvae were fed young corn leaves and adults were fed mashed bananas.

\section{CRISPR-Cas9}

optix and spalt CRISPR experiments were carried out based on a protocol previously described (Banerjee and Monteiro, 2018). Guides were designed to target the coding sequence of the genes (see the supplementary file for sequences and the regions targeted). A solution containing Cas9 protein (IDT, Cat No. 1081058) and guide RNA, each at a concentration of 300ng/ul, diluted in Cas 9 buffer, and a small amount of food dye was injected in 1509 embryos for optix and 863 embryos for spalt (Table S1 and S2.). A few of these injected individuals were dissected at $24 \mathrm{hrs}$ after pupation to perform immunostainings, while the rest were allowed to grow till adulthood. After eclosing, the adults were frozen at $-20^{\circ} \mathrm{C}$ and imaged under a Leica DMS1000 microscope.

\section{Immunostainings}

Pupation time was recorded using an Olympus tough tg-6 camera, and pupal wings were dissected at different timepoints after pupation under a Zeiss Stemi 305 microscope in 1x PBS at room temperature based on a protocol previously described (Banerjee and Monteiro, 2020b). Wings were fixed using 4\% formaldehyde in fix buffer (see Table $\mathbf{S 3}$ for details), followed by 
bioRxiv preprint doi: https://doi org/10.1101/2021.05.22.445259; this version posted May 23, 2021. The copyright holder for this preprint

four washes in 1x PBS, five mins each. After the washes, the wings were incubated in block buffer (see Table S3 for details) at $4^{\circ} \mathrm{C}$ overnight. The next day primary antibodies against Optix (1:3000, rat, a gift from Robert D. Reed) and Spalt (1:20000, guinea pig GP66.1), were added in wash buffer and incubated at $4^{\circ} \mathrm{C}$ for $24 \mathrm{hrs}$. The next day anti-rat AF488 (Invitrogen, \#A-11006) and anti-guinea pig AF555 (Invitrogen, \# A-21435) secondary antibodies at the concentration of 1:500 in wash buffer were added followed by four washes in wash buffer, 20 mins each. Wings were then mounted on an inhouse mounting media (see Table $\mathbf{S 3}$ for details) and imaged under an Olympus fv3000 confocal microscope.

\section{In-situ hybridization}

For the visualization of $d p p$ expression in pupal wings of Bicyclus, pupation time was recorded, and the wings were dissected from 20-24 hrs old pupae in 1x PBS under a Zeiss stemi 305 microscope based on a previously described protocol (Banerjee and Monteiro, 2020b) and transferred to 1 xPBST with $4 \%$ formaldehyde. After fixation for $30 \mathrm{~min}$ the wings were washed three times in 1x PBST for 5 mins each. The wings were then treated with proteinase $\mathrm{K}$ and glycine and washed again three times using 1x PBST. After, the wings were gradually transferred into pre-hybridization buffer (see Table $\mathbf{S} 4$ for composition) and heated at $65^{\circ} \mathrm{C}$ for $1 \mathrm{hr}$. Hybridization buffer with a $d p p$ probe (see Table $\mathbf{S} 4$ for composition) was added to the wings and they were incubated for $16 \mathrm{hrs}$ at $65^{\circ} \mathrm{C}$. Wings were then washed five times for 30 mins each in pre-hybridization buffer. After washing, wings were moved to room temperature and gradually transferred to 1x PBST and washed in 1x PBST. Afterwards, the wings were incubated in block buffer (see Table $\mathbf{S} 4$ for composition) for $1 \mathrm{hr}$, followed by addition of antidigoxygenin (Sigma-Aldrich, Cat No. 11093274910) diluted 1/3000 times in block buffer. After $1 \mathrm{hr}$ of incubation the wings were washed five time, five mins each in block buffer. Finally, wings were transferred to alkaline-phosphatase buffer (see supp table S4 for composition) supplemented with NBT-BCIP (Promega, Cat No. S3771) and incubated in the dark till the development of color. The wings were imaged under a Leica DMS1000 microscope.

\section{Scanning Electron microscopy}

A fine metal needle was used to pick scales from adult WT and optix crispant wings. The scales were then mounted on a carbon tape fixed to an SEM stub, platinum coated using JEOL JFC1600 Auto Fine Coater and imaged under a JEOL JSM-6701F Field-Emission SEM.

\section{Scale absorbance measurements}

Individual scales were placed on a glass slide and immersed in clove oil with a refractive index of 1.53. The scales were then covered with a coverslip and absorbance was measured using Technospex uSight-2000 Microspectroscopy system. Ten scales were measured for each color type, with measurements taken from three areas on each scale. Measurements were analysed using the R package 'pavo' (see supplementary file for code).

\section{Funding}

This work was supported by the National Research Foundation (NRF) Singapore, Investigatorship award NRF-NRFI05-2019-0006 to AM. TDB and SKS were supported by Yale-NUS scholarship.

\section{Acknowledgements}


bioRxiv preprint doi: https://doi.org/10.1101/2021.05.22.445259. this version posted May 23, 2021. The copyright holder for this preprin (which was not certified by peer review) is the author/funder, who has granted bioRxiv a license to display the preprint in perpetuity. It is made available under aCC-BY-ND 4.0 International license.

We would like to thank Robert Reed for the anti-Optix antibody; Lee Ka Yau (SEM facility, Department of Chemistry, NUS) for the help with imaging the SEM samples. We would like to thank DBS-CBIS confocal facility and Ms. Tong Yan for access and help with the Olympus fv3000 confocal microscope. The authors declare no conflict of interest.

\section{Authors contribution}

TDB and AM designed the experiments, analysed the results, and wrote the manuscript. TDB performed the experiments. SKS measured the absorbance spectra of the scales. All the authors read and agreed to the final version of the manuscript.

\section{References}

Banerjee, T. Das, and Monteiro, A. (2020a). Molecular mechanisms underlying simplification of venation patterns in holometabolous insects. Development dev.196394.

Banerjee, T. Das, and Monteiro, A. (2020b). Dissection of Larval and Pupal Wings of Bicyclus anynana Butterflies. Methods Protoc. 3, 5.

Banerjee, T., and Monteiro, A. (2018). CRISPR-Cas9 Mediated Genome Editing in Bicyclus anynana Butterflies.

Beldade, P., and Monteiro, A. (2021). Eco-evo-devo advances with butterfly eyespots. Curr. Opin. Genet. Dev. 6-13.

Bergen, E., and Beldade, P. (2019). Seasonal plasticity in anti-predatory strategies: Matching of color and color preference for effective crypsis. Evol. Lett. 3, 313-320.

Brakefield, P.M., Gates, J., Keys, D., Kesbeke, F., Wijngaarden, P.J., Monteiro, a, French, V., and Carroll, S.B. (1996). Development, plasticity and evolution of butterfly eyespot patterns. Nature 384, $236-242$.

Brunetti, C.R., Selegue, J.E., Monteiro, A., French, V., Brakefield, P.M., and Carroll, S.B. (2001). The generation and diversification of butterfly eyespot color patterns. Curr. Biol. 11, 1578-1585.

Jiggins, C.D., Wallbank, R.W.R., and Hanly, J.J. (2017). Waiting in the wings: What can we learn about gene co-option from the diversification of butterfly wing patterns? Philos. Trans. R. Soc. B Biol. Sci. 372.

Al Khatib, A., Siomava, N., Iannini, A., Posnien, N., and Casares, F. (2017). Specific expression and function of the Six3 optix in Drosophila serially homologous organs. Biol. Open 6, 1155-1164.

Li, Y., Jiang, Y., Chen, Y., Karandikar, U., Hoffman, K., Chattopadhyay, A., Mardon, G., and Chen, R. (2013). Optix functions as a link between the retinal determination network and the dpp pathway to control morphogenetic furrow progression in Drosophila. Dev. Biol. 381, 50-61.

Livraghi, L., Hanly, J.J., Loh, L.S., Ren, A., and Warren, I.A. (2020). The gene cortex controls scale colour identity in Heliconius. 1-30.

Martin, A., McCulloch, K.J., Patel, N.H., Briscoe, A.D., Gilbert, L.E., and Reed, R.D. (2014). Multiple recent co-options of Optix associated with novel traits in adaptive butterfly wing radiations. Evodevo 5, 1-13.

Martín, M., Ostalé, C.M., and De Celis, J.F. (2017). Patterning of the drosophila L2 vein is driven by regulatory interactions between region-specific transcription factors expressed in response to Dpp signalling. Dev. 144, 3168-3176.

Merzendorfer, H., and Zimoch, L. (2003). Chitin metabolism in insects: Structure, function and regulation of chitin synthases and chitinases. J. Exp. Biol. 206, 4393-4412. 
bioRxiv preprint doi: https://doi. org/10.1101/2021.05.22 445259; this version posted May 23, 2021. The copyright holder for this preprint (which was not certified by peer review) is the author/funder, who has granted bioRxiv a license to display the preprint in perpetuity. It is made available under aCC-BY-ND 4.0 International license.

Monteiro, A., Glaser, G., Stockslager, S., Glansdorp, N., and Ramos, D. (2006). Comparative insights into questions of lepidopteran wing pattern homology. BMC Dev. Biol. 6, 52.

Nadeau, N.J., Pardo-diaz, C., Whibley, A., Supple, M.A., Suzanne, V., Richard, W., Wu, G.C., Maroja, L., Ferguson, L., Hanly, J.J., et al. (2016). The gene cortex controls mimicry and crypsis in butterflies and moths. Nature 534, 106-110.

Nijhout, H.F. (1978). Wing pattern formation in Lepidoptera: A model. J. Exp. Zool. 206, 119-136.

Quiring, R., Walldorf, U., Kloter, U., and Gehring, W.J. (1994). Homology of the eyeless gene of drosophila to the small eye gene in mice and aniridia in humans. Science (80-. ). 265, 785-789.

Rauser, C.L., and Rutowski, R.L. (2003). Male-specific structures on the wings of the gulf fritillary butterfly, Agraulis vanillae (Nymphalidae). J. Lepid. Soc. 57, 279-283.

Reed, R.D., Papa, R., Martin, A., Hines, H.M., Kronforst, M.R., Chen, R., Halder, G., Nijhout, H.F., and Mcmillan, W.O. (2011). optix Drives the Repeated Convergent Evolution of Butterfly Wing Pattern Mimicry. Science (80-. ). 333, 1137-1141.

Seimiya, M., and Gehring, W.J. (2000). The Drosophila homeobox gene optix is capable of inducing ectopic eyes by an eyeless-independent mechanism. Development 127, 1879-1886.

Sturtevant, M. a, Biehs, B., Marin, E., and Bier, E. (1997). The spalt gene links the A/P compartment boundary to a linear adult structure in the Drosophila wing. Development 124, 21-32.

Thayer, R.C., Allen, F.I., and Patel, N.H. (2020). Structural color in Junonia butterflies evolves by tuning scale lamina thickness. Elife 9:e52187, 1-21.

van't Hof, A.E., Campagne, P., Rigden, D.J., Yung, C.J., Lingley, J., Quail, M.A., Hall, N., Darby, A.C., and Saccheri, I.J. (2016). The industrial melanism mutation in British peppered moths is a transposable element. Nature 534, 102-105.

Zecca, M., Basler, K., and Struhl, G. (1996). Direct and long range action of a DPP morphogen gradient. Cell 87, 833-844.

Zhang, L., Mazo-Vargas, A., and Reed, R.D. (2017). Single master regulatory gene coordinates the evolution and development of butterfly color and iridescence. Proc. Natl. Acad. Sci. 114, 1070710712.

\section{Supplementary materials}


bioRxiv preprint doi: https://doi org/10.1101/2021.05.22 445259- this version posted May 23,2021 . The copyright holder for this preprint made available under aCC-BY-ND 4.0 International license.

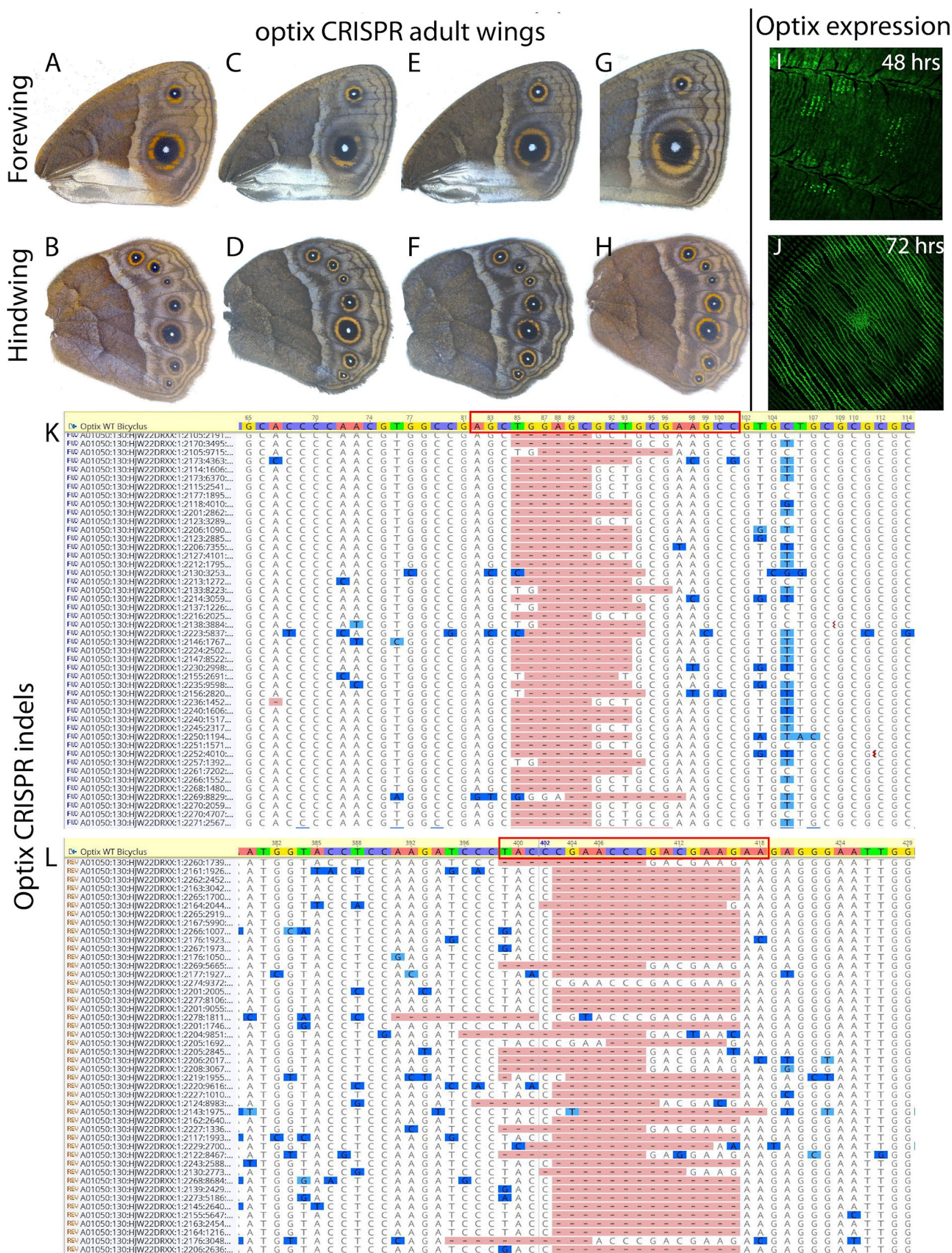

Figure S1. Expression and function of Optix in Bicyclus anynana butterflies. (A-H) optix CRISPR adult wings. optix CRISPR results in the conversion of orange scales into brown scales in the eyespots. (I and J) Antibody staining of an Optix CRISPR individual at $48 \mathrm{hrs}$ and a WT 72 hrs old pupal wing. (K and L) Deletions at the two sites targeted for optix CRISPR. 


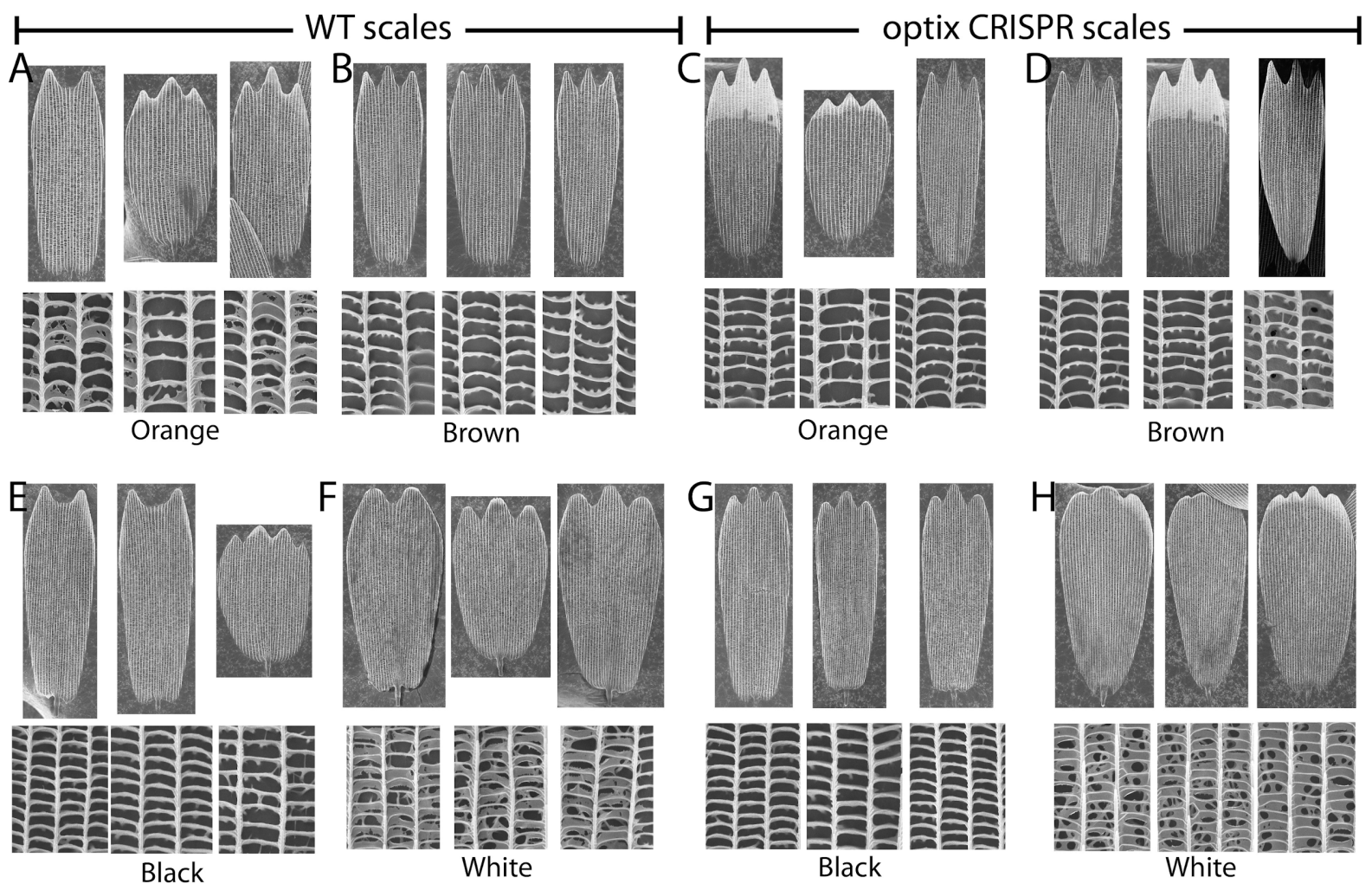

Figure S2. WT and optix CRISPR scale ultrastructures. WT orange (A) have higher amount of upper lamina in between the crossribs compared to optix CRISPR orange (C) similar to the brown scales (B and D). There are no changes in the scale structure of black and white scale structures in between the WT and optix CRISPR (E-H). 

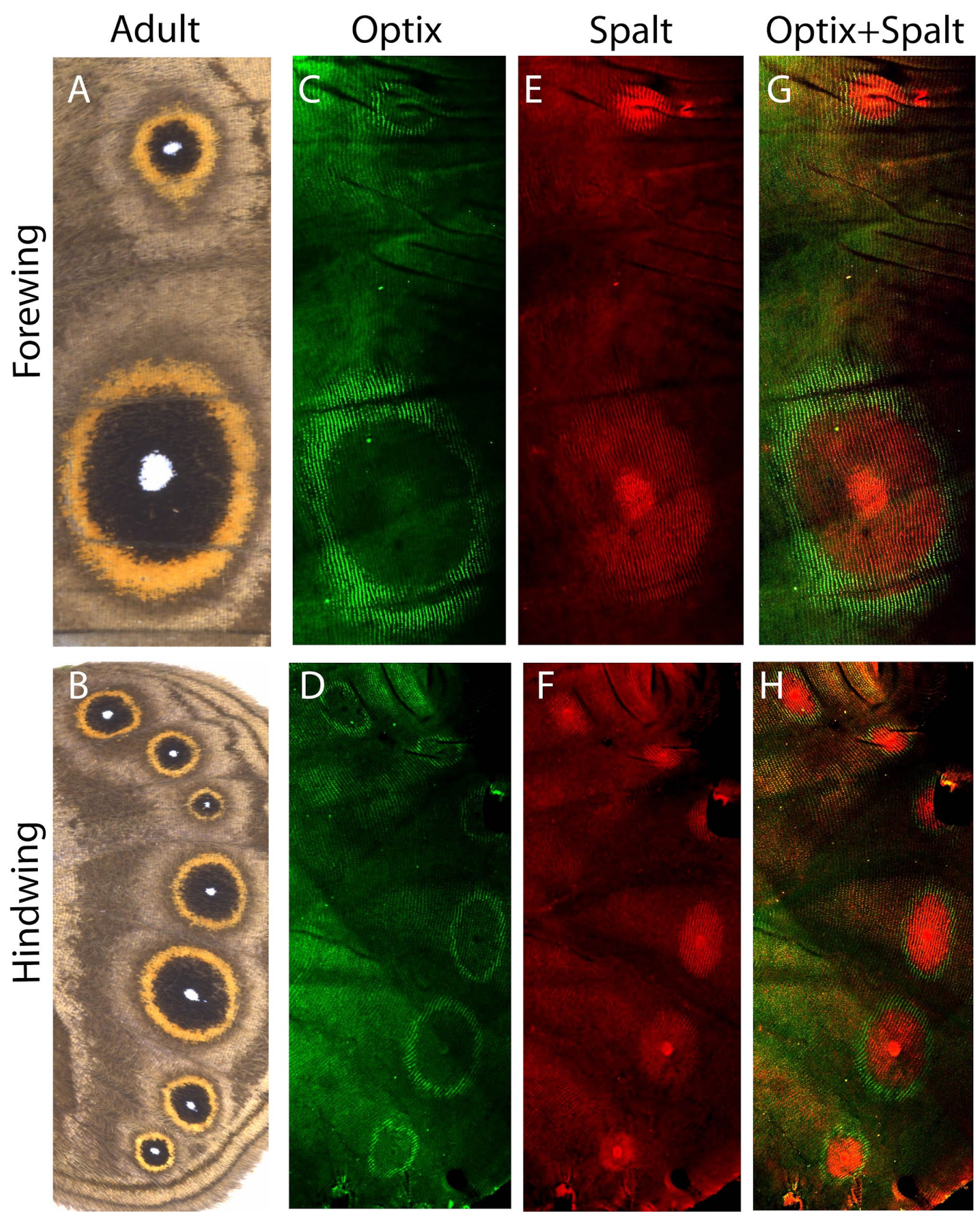

Figure S3. Bicyclus adult wings and the expression of Optix and Spalt in 16-20 hrs old pupal wings. (A and B) Adult forewing and hindwing. (C and D) Optix expression in the forewing and hindwing. (E and F) Spalt expression in the forewing and hindwing. (G and $\mathbf{H}$ ) Merged channels of Optix and Spalt. 


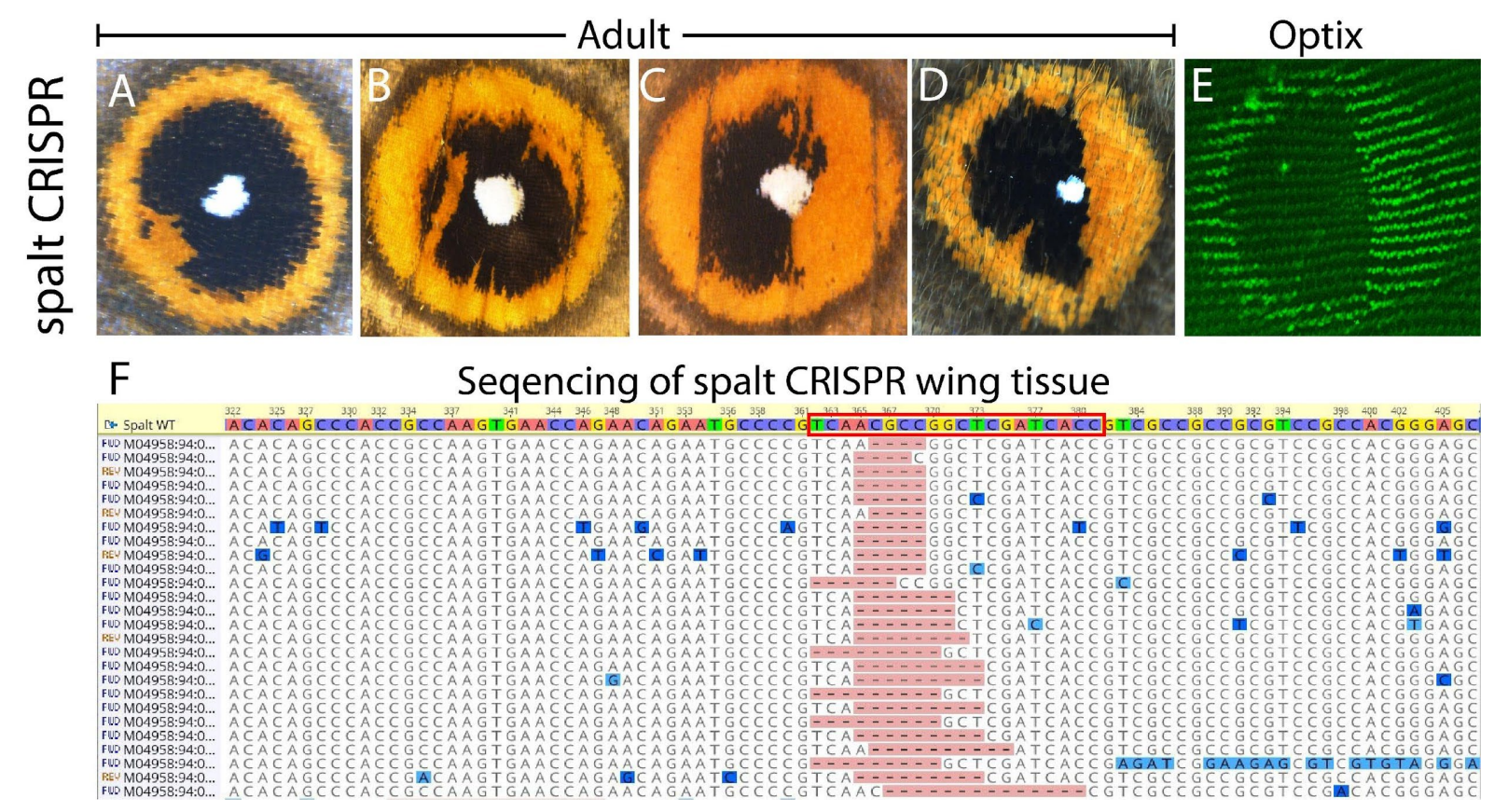

Figure S4: Effect of spalt CRISPR on the eyespots. (A-D) Loss of Spalt results in the development of orange scales in the black scale region due to the expression of (E) Optix in that region. (F) Deletion at the site of spalt CRISPR (red box).

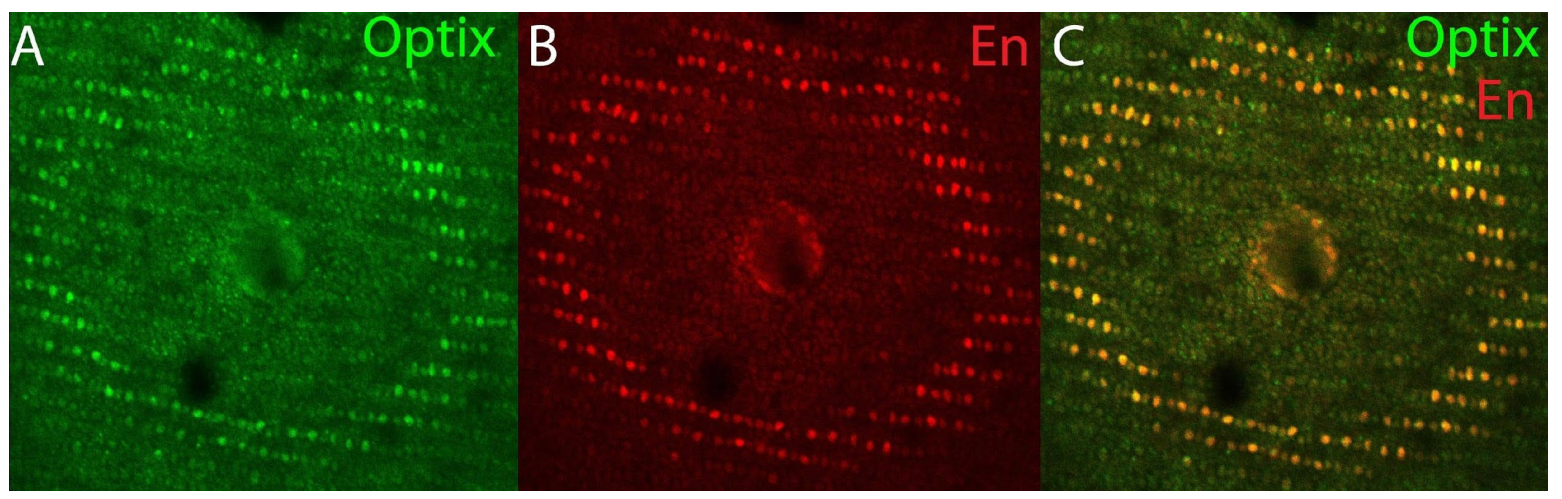

Figure S5. Co-expression of Optix and Engrailed (En) in the orange ring of the eyespots. Both (A) Optix and (B) En are present in the cells that will form the orange scales of the eyespot.

Table S1. Optix CRISPR-Cas9 injection table

\begin{tabular}{|c|c|c|c|c|c|}
\hline $\begin{array}{c}\text { Sl. } \\
\text { No. }\end{array}$ & Concentration & Date & $\begin{array}{c}\text { Eggs } \\
\text { Injected }\end{array}$ & Hatchlings & $\begin{array}{c}\% \\
\text { Hatchlings }\end{array}$ \\
\hline $\mathbf{1 .}$ & $300 \mathrm{ng} / \mu \mathrm{l}$ & $6^{\text {th }}$ June 2020 & 326 & 65 & 19.9 \\
\hline $\mathbf{2 .}$ & $300 \mathrm{ng} / \mu \mathrm{l}$ & $9^{\text {th }}$ July 2020 & 923 & 126 & 13.6 \\
\hline $\mathbf{3 .}$ & $300 \mathrm{ng} / \mu \mathrm{l}$ & $27^{\text {th }}$ Aug 2020 & 389 & 88 & 22.6 \\
\hline
\end{tabular}

Table S2. Spalt CRISPR-Cas9 injection table 


\begin{tabular}{|c|c|c|c|c|c|}
\hline $\begin{array}{c}\text { Sl. } \\
\text { No. }\end{array}$ & Concentration & Date & $\begin{array}{c}\text { Eggs } \\
\text { Injected }\end{array}$ & Hatchlings & $\begin{array}{c}\text { \% } \\
\text { Hatchlings }\end{array}$ \\
\hline $\mathbf{1 .}$ & $300 \mathrm{ng} / \mu \mathrm{l}$ & $\begin{array}{c}23^{\text {rd }} \text { June } \\
2020\end{array}$ & 276 & 39 & 14.1 \\
\hline $\mathbf{2 .}$ & $300 \mathrm{ng} / \mu \mathrm{l}$ & $28^{\text {th }}$ Aug 2020 & 593 & 74 & 12.5 \\
\hline $\mathbf{3 .}$ & $300 \mathrm{ng} / \mu \mathrm{l}$ & $8^{\text {th }}$ Sep 2020 & 879 & 106 & 12.1 \\
\hline $\mathbf{4 .}$ & $300 \mathrm{ng} / \mu \mathrm{l}$ & $24^{\text {th }}$ Sep 2020 & 726 & 65 & 9.0 \\
\hline
\end{tabular}

Table S3. Immunofluorescence Buffers

\begin{tabular}{|c|c|c|}
\hline Buffers & Chemicals & Amount \\
\hline \multirow[t]{6}{*}{ Fix buffer $(30 \mathrm{ml})$} & $\begin{array}{c}\text { 0.1M PIPES pH } 6.9(500 \\
\text { mM })\end{array}$ & $6 \mathrm{ml}$ \\
\hline & $\begin{array}{c}1 \text { mM EGTA pH } 6.9 \\
(500 \mathrm{mM})\end{array}$ & $60 \mu 1$ \\
\hline & $1 \%$ Triton $\mathrm{x}-100(20 \%)$ & $1.5 \mathrm{ml}$ \\
\hline & $2 \mathrm{mM} \mathrm{MgSO}_{4}(1 \mathrm{M})$ & $60 \mu 1$ \\
\hline & $37 \%$ Formaldehyde & $55 \mu 1$ per $500 \mu 1$ of buffer \\
\hline & $\mathrm{dH}_{2} \mathrm{O}$ & $22.4 \mathrm{ml}$ \\
\hline \multirow[t]{5}{*}{ Block buffer $(40 \mathrm{ml})$} & $50 \mathrm{mM}$ Tris pH $6.8(1 \mathrm{M})$ & $2 \mathrm{ml}$ \\
\hline & $150 \mathrm{mM} \mathrm{NaCl}(5 \mathrm{M})$ & $1.2 \mathrm{ml}$ \\
\hline & $\begin{array}{l}0.5 \% \text { IGEPAL (NP40) } \\
(20 \%)\end{array}$ & $1 \mathrm{ml}$ \\
\hline & $5 \mathrm{mg} / \mathrm{ml} \mathrm{BSA}$ & $0.2 \mathrm{gr}$ \\
\hline & $\mathrm{H} 2 \mathrm{O}$ & $35.8 \mathrm{ml}$ \\
\hline \multirow[t]{5}{*}{ Wash buffer $(200 \mathrm{ml})$} & 50mM Tris $\mathrm{pH} 6.8(1 \mathrm{M})$ & $10 \mathrm{ml}$ \\
\hline & $150 \mathrm{mM} \mathrm{NaCl}(5 \mathrm{M})$ & $6 \mathrm{ml}$ \\
\hline & $0.5 \%$ IGEPAL $(20 \%)$ & $5 \mathrm{ml}$ \\
\hline & $1 \mathrm{mg} / \mathrm{ml} \mathrm{BSA}$ & $0.2 \mathrm{gr}$ \\
\hline & $\mathrm{dH}_{2} \mathrm{O}$ & $179 \mathrm{ml}$ \\
\hline \multirow[t]{3}{*}{ Mounting media } & Tris-HCl (pH 9.2) & $20 \mathrm{mM}$ \\
\hline & $\mathrm{N}$-propyl gallate & $0.5 \%$ \\
\hline & Glycerol & $60 \%$ \\
\hline
\end{tabular}




\begin{tabular}{|c|c|c|}
\hline Buffers & Chemicals & Amount \\
\hline \multirow{4}{*}{$\begin{array}{c}\text { 10X PBS (500 ml) } \\
\text { * Sterilize by } \\
\text { autoclaving. }\end{array}$} & $\mathrm{K}_{2} \mathrm{HPO}_{4}$ & $5.34 \mathrm{~g}$ \\
\hline & $\mathrm{KH}_{2} \mathrm{PO}_{4}$ & $2.64 \mathrm{~g}$ \\
\hline & $\mathrm{NaCl}$ & $40.9 \mathrm{~g}$ \\
\hline & DEPC treated $\mathrm{H}_{2} \mathrm{O}$ & To $500 \mathrm{ml}$ \\
\hline \multirow[t]{2}{*}{$1 X$ PBST $(50 \mathrm{ml})$} & $1 X$ PBS & $50 \mathrm{ml}$ \\
\hline & Tween $^{\circledR} 20$ & $50 \mu \mathrm{l}$ \\
\hline \multirow{3}{*}{$\begin{array}{l}\text { 20X SSC (1000 ml) } \\
\text { *Adjust the } \mathrm{pH} \text { to } 7.0 \\
\text { with } 1 \mathrm{M} \mathrm{HCl} \text { and sterilize } \\
\text { by autoclaving. }\end{array}$} & $\mathrm{NaCl}$ & $175.3 \mathrm{~g}$ \\
\hline & Trisodium citrate & $88.2 \mathrm{~g}$ \\
\hline & DEPC treated $\mathrm{H}_{2} \mathrm{O}$ & Till $1000 \mathrm{ml}$ \\
\hline \multirow{4}{*}{$\begin{array}{l}\text { Pre-hybridization buffer } \\
\qquad(40 \mathrm{ml})\end{array}$} & Formamide & $20 \mathrm{ml}$ \\
\hline & $20 \times$ SSC & $10 \mathrm{ml}$ \\
\hline & DEPC treated water & $10 \mathrm{ml}$ \\
\hline & TWEEN20 & $40 \mu \mathrm{l}$ \\
\hline \multirow{6}{*}{$\begin{array}{l}\text { Hybridization buffer (40 } \\
\text { ml) }\end{array}$} & Formamide & $20 \mathrm{ml}$ \\
\hline & $20 \times \mathrm{SSC}$ & $10 \mathrm{ml}$ \\
\hline & DEPC treated water & $10 \mathrm{ml}$ \\
\hline & TWEEN20 & $40 \mu \mathrm{l}$ \\
\hline & Salmon sperm & $40 \mu \mathrm{l}$ \\
\hline & Glycine $(100 \mathrm{mg} / \mathrm{ml})$ & $40 \mu \mathrm{l}$ \\
\hline \multirow[t]{3}{*}{ Block buffer $(50 \mathrm{ml})$} & $1 X$ PBS & $50 \mathrm{ml}$ \\
\hline & TWEEN20 & $50 \mu \mathrm{l}$ \\
\hline & BSA & $0.1 \mathrm{gm}$ \\
\hline \multirow{5}{*}{$\begin{array}{l}\text { Alkaline phosphatase } \\
\text { buffer }(20 \mathrm{ml})\end{array}$} & Tris-HCl (pH 8.0) & $2 \mathrm{ml}$ \\
\hline & $\mathrm{NaCl}(5 \mathrm{M})$ & $400 \mu l$ \\
\hline & $\mathrm{MgCl}_{2}(200 \mathrm{mM})$ & $250 \mu \mathrm{l}$ \\
\hline & DEPC treated water & Till $20 \mathrm{ml}$ \\
\hline & TWEEN20 & $20 \mu \mathrm{l}$ \\
\hline
\end{tabular}


$\underline{\text { Sequence of decapentaplegic used for in-situ hybridization. }}$

GTTCTTCAACGTAAGCGGCGTACCGGCCGACGAGGTGGCGCGCGGCGCCGACCT CTCGTTCCAACGAGCCGTCGGCACCACCGGCAGACAGAGACTGTTGTTGTACGA CGTGGTGCGCCCTGGCCGCCGCGGCCACTCCGAGCCGATCCTGCGGCTGCTGGAC TCCGTTCCGCTCCGGCCCGGGGAGGGAATCGTCAACGCCGACGCTCTGGGAGCG GCGCGACGGTGGCTCAAAGAGCCCAAACATAATCACGGACTATTAGTGCGAGTG TTAGAAGAAGACGCCGCGAGTGCGAGCAGGGACGCGAAGTTCCCGCACGTGCGC GTGCGCAGACGCGTCACGGACGAGGAGGAGGAGTGGCGGACGGCGCAGCCGCT GCTCATGCTGTACACGGAGGACGAGCGCGCGCGCGCGTCGCGGGAGACGAGCGA GCGGCTGACGCGCAGCAAGCGCGCGGCGCAGCGGCGGGGGCACCGCGCGCACC ACCGCCGCAAGGAGGCGCGCGAGATCTGCCAGCGCCGCCCGCTGTTCGTCGACT TCGCGGACGTGGGCTGGAGCGACTGGATCGTGGCCCCGCACGGCTACGACGCGT ACTACTGCCAGGGCGACTGCCCCTTCCCGCTGCCGGACCACCTCAACGGCACGA ACCACGCGATAGTGCAGACTCTGGTCAACTCAGTGAACCCCGCGACGGTGCCCA AAGCGTGCTGCGTGCCGACGCAACTCTCATCTATATCTATGTTATATATGGACGA AGTGAACAATGTGGTGCTTAAAAACTATCAGGACATGATGGTGGTAGGCTGTGG

Region of optix used for CRISPR-Cas9 (Highlighted in red)

ATGCGCGGCTCCTGGGACGAGTCCACGACGGCGGCGCTGCACGCGCGCATCCTG GAGGCGCACCGCGGGTCCGCCGCGCCCGACCGCGCCGAGCCCGCGTGCGAGCCT CCGCCGCTGACGCTGGGCGCGCTGGAGCTGGCGGCGCCCACGCCGCTGCTGCCG CTGCCCACGCTGAGCTTCAGCGCCGCGCAGGTGGCCACCGTGTGCGAGACGCTG GAGGAGAGCGGCGACGTGGAGCGCCTGGCGCGCTTCTTGTGGTCGCTGCCCGTG GCGCACCCCAACGTGGCCGAGCTGGAGCGCTGCGAAGCCGTGCTGCGCGCGCGC GCCGTCGTCGCCTTCCACGCCGGCCGCCACCGCGAGCTGTACGCCATCCTCGAGC GCCACCGCTTCCAGCGCTCCAGCCACGCCAAGCTGCAAGCGCTGTGGCTGGAGG CGCACTACCAGGAGGCTGAGCGCCTGCGCGGCCGTCCGCTGGGCCCCGTCGACA AGTACCGCGTGCGGAAGAAGTTCCCGCTCCCGAGGACGATCTGGGACGGCGAGC AGAAGACGCACTGTTTCAAGGAGCGGACGCGATCTCTACTCCGAGAATGGTACC TCCAAGATCCCTACCCGAACCCGACGAAGAAGAGGGAATTGGCGGCGGCGACGG GTCTGACGCCGACGCAAGTCGGCAACTGGTTCAAAAACCGACGGCAAAGAGACC GAGCGGCCGCCGCCAAGAACCGCTCCGCCGTGCTGGGCAGAGGATAA

$\underline{\text { Region of spalt targeted by CRISPR-Cas9 (location of guide RNA highlighted in red) }}$

GCATCGACAAGATGCTGAAAATAATAATAGTCTCGAAGACGGCGAGGCCGAAAT ACCTGAAGCCGACATGCCCCCCGTGGGTCTGCCGTTCCCTTTGGCAGGACACGTT ACTCTTGAGGCTCTACAAAATACGAGAGTAGCGGTCGCCCAATTCGCTGCAACA GCGATGGCAAATAATGCGAATAACGAAGCTGCTATACAAGAATTACAAGTGTTA CACAACACTCTATACACTTTACAGTCACAACAAGTATTTCAACTTCAGTTAATAC GTCAGCTTCAGAATCAGTTATCTCTAACTCGACGGAAAGAAGACGATCCACACA GCCCACCGCCAAGTGAACCAGAACAGAATGCCCCGTCAACGCCGGCTCGATCAC CGTCGCCGCCGCGTCCGCCACGGGAGCCGTCGCCTGTTATACCCTCTCCTCCTAC TAGCCAAAGTTTGCCGTCGACTCACACACATCACACACCCAAAACTGAACAGAT ATCTATCCCTAAGATTCCAACTTCCTCACCATCTTTAATGACCCACCCACTTTATA 
bioRxiv preprint doi: https://doi.org/10.1101/2021.05.22.445259; this version posted May 23, 2021. The copyright holder for this preprint

(which was not certified by peer review) is the author/funder, who has granted bioRxiv a license to display the preprint in perpetuity. It is made available under aCC-BY-ND 4.0 International license.

\section{GTTCAATTTCTTCGTCATTAGCATCTTCCATCATAACAAACAATGATCCTCCACCG TCCCTAAATGAA}

\section{R-code for the absorbance spectra analysis}

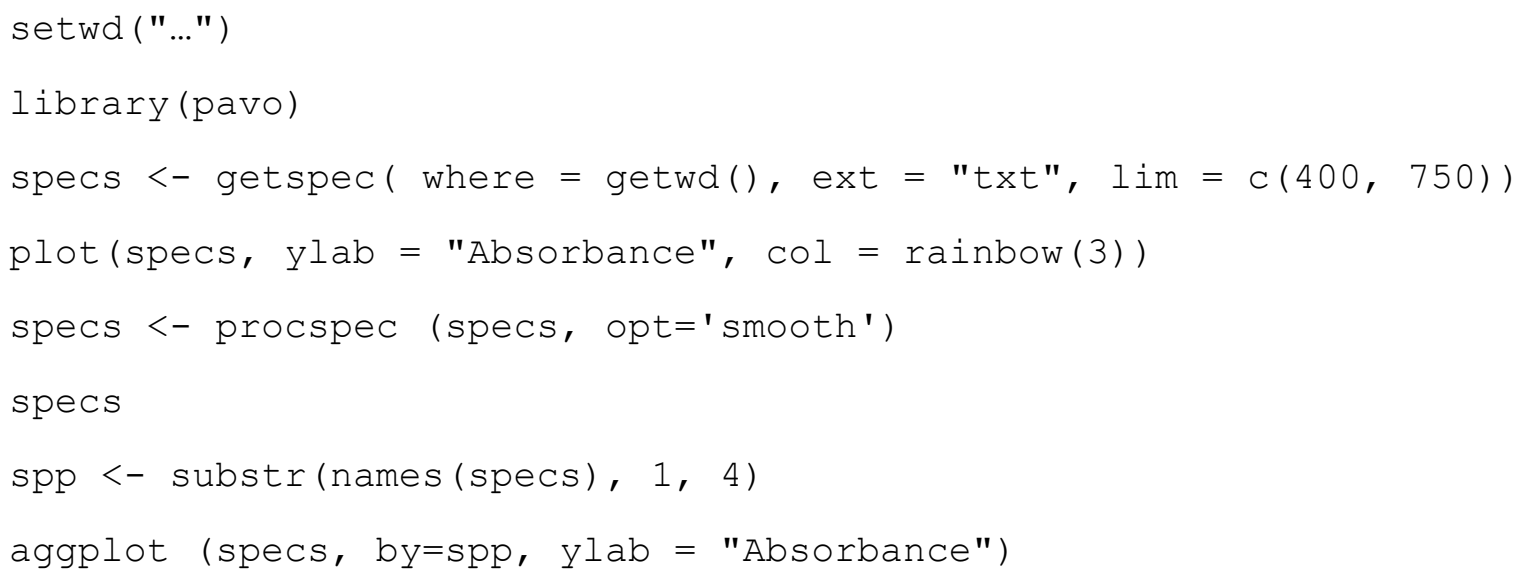

